\title{
On the prepositional nature of non-finite verbs*
}

\author{
Ángel J. Gallego \\ Universitat Autònoma de Barcelona. Centre de Lingüística Teòrica \\ 08193 Bellaterra (Barcelona). Spain \\ angel.gallego@uab.cat
}

Received: April 162010

Accepted: September 42010

\begin{abstract}
This paper investigates the prepositional nature of non-finite verbal forms. Assuming well-known observations that relate the categories P and V on the one hand (see Chomsky 1970, 1981, Demirdache \& Uribe-Etxebarria 2000, Hale \& Keyser 2002, and Svenonius 2003, 2007, 2008, among others), and P and C on the other (see den Besten 1983, Emonds 1985, Kayne 2000, and van Riemsdijk 1978) I argue that some non-finite verbs - in particular, past participles and gerunds-incorporate a preposition as a result of the interaction between the categories $\mathrm{C}$ and $\mathrm{T}$, which can manifest itself as a species of $\mathrm{P}$ in non-finte contexts (see Demirdache \& UribeEtxebarria 2000, and Pesetsky \& Torrego 2004). This approach not only explains different syntactic facts concerning non-finite clauses, but also sheds some light on their interpretive intricacies.
\end{abstract}

Key words: category, infinitive, gerund, participle, preposition, Aux/T-to-C movement, verb.

\section{Table of Contents}

1. Introduction

2. The empirical observation

3. The nature of non-finite $\mathrm{C}$
4. Some consequences of the proposal

5. Conclusions

References

\section{Introduction}

Much recent literature on the lexicon-syntax interface (see Hale \& Keyser 1993, Harley 2005, Marantz 1997, 2001, Pesetsky 1995, Ramchand 2008, among others) has led to a new view of categorial labels. Departing from traditional conceptions, whereby the category of a lexical item is conceived of as an inherent property, many contemporary approaches entertain the idea that lexical categories obtain from an acategorial root element combining with a light functional category, whose

* For comments and suggestions, I would like to thank Cedric Boeckx, M. Lluïsa Hernanz, Jonathan MacDonald, Carme Picallo, Gemma Rigau, Juan Romero, and Juan Uriagereka. Thanks also to an anonymous reviewer, whose observations helped me clarify some issues under discussion. This research has been partially supported by grants from the Ministerio de Educación y Ciencia-FEDER (HUM2006-13295-C02-02), and from the Generalitat de Catalunya (2009SGR-1079). 
semantic nature - its 'flavor' - is configurationally determined (see Folli \& Harley 2005 and references therein). Such a perspective has opened the door not only to reconsider the nature of syntactic primitives and the nature of the lexicon (see Borer 2005, Halle \& Marantz 1993, Starke 2009), but also to make available a more dynamic conception of what a lexical category is: verbs may contain a prepositional, nominal, or adjectival component (in, e.g., locatum, unergative, and resultative verbs, respectively), or have a hybrid nature, actually displaying a dual nature (e.g., John's reading the book).

A fairly standard assumption within these approaches is that prepositions and verbs are two (functional) categories that must be teased apart: (light) verbs categorize roots, prepositions do not; (light) verbs assign structural Case, prepositions do inherent Case; (light) verbs encode $\varphi$-features, prepositions do not (in most languages); etc. Although these facts are all well-established, a parallel trend in the literature has nonetheless emphasized the properties that these categories share. Perhaps the most popular one goes back to Chomsky's $(1970,1981)$ characterization of verbs and prepositions as [-N] categories, but work on argument structure has contributed to strengthen the similarities between these two categories (see Demirdache \& Uribe-Etxebarria 2000, Hale \& Keyser 2002, and Svenonius 2003, 2007, 2008). ${ }^{1}$ This, together with the empirical evidence pointing to the cyclic (currently, phasal) nature of both P and v/C (see Abels 2003, den Besten 1983, Emonds 1985, Kayne 2000, and van Riemsdijk 1978), suggests that a crystal-clear cut between what we call 'verb' and 'preposition' is not immediately obvious.

In this paper I would like to explore the prepositional nature of non-finite verbs, focusing on the properties displayed by Spanish infinitives, gerunds, and past participles. In particular, adopting the basics of Pesetsky \& Torrego's (2001 et seq.) framework, I claim that, contrary to infinitives, gerunds and past participles incorporate a preposition of sorts. I will take the preposition to correspond to the -ing and -ed morphemes of non-finite verbs in Spanish, which will be treated as the way T is spelled-out in gerund and past participial clauses. Such an analysis will not only provide additional support for the idea that prepositions and verbs are, quite plausibly, the very same abstract category (as work by Demirdache \& Uribe-Etxebarria 2000, Hale \& Keyser 2002, Svenonius 2008, Torrego 1999, and others has underscored, both verbs and prepositions express properties such as aspect, tense, mood, or voice), but will also account for the syntactic behavior of gerunds and past participles, as well as for their semantic interpretation.

Discussion is divided as follows: Section 2 spells-out the empirical focus of this paper, namely non-finite clauses in Spanish. Section 3 introduces some background discussion about the connection between $\mathrm{C}, \mathrm{D}$, and $\mathrm{P}$, and the hypothesis that verbs may involve a hidden $\mathrm{P}$ or a hidden $\mathrm{D}$. In section $4 \mathrm{I}$ argue that the semantic interpretation of adjunct (non-finite) clauses follows from the lexico-semantic

1. An anonymous reviewer asks why I assume that Hale and Keyser argued for the collapsing of $P$ and V. I am not suggesting that, all I am pointing out is that, within Hale \& Keyser's (1993 et seq.) system, prepositions and verbs have been shown to share certain traits (they are both relational, they have both different flavors, etc.). If correct, this would favor the parallelism I am arguing for. 
nature of the $\mathrm{P}$ they incorporate (in the sense of Hale 1986). Section 5 summarizes the main conclusions.

\section{The empirical observation}

Within the Spanish tradition, grammarians often assumed that non-finite verbs had a hybrid categorial status. Even though they could not resort a technical apparatus at the time, they had the clear intuition that infinitives, gerunds, and past participles should be regarded as 'verbal nouns', 'verbal adverbs', and 'verbal adjectives' respectively (see Bello 1847: $\S \S 419,427$, and 442; RAE 1973: $\S 3.16$ and ff.; for recent discussion, see Bosque 1989). Consider, for instance, the Esbozo's take on the issue:

The most common meaning that corresponds to each of these non-personal forms can be defined saying that the infinitive is a verbal noun; the gerund, a verbal adverb; and the participle, a verbal adjective.

[form RAE 1973: 483—my translation, AJG—]

Such a three-way distinction had, essentially, a functional basis. As the examples in (1-3) show, non-finite clauses can indeed 'function' - distributionally-as nouns, adjectives, and adverbs.

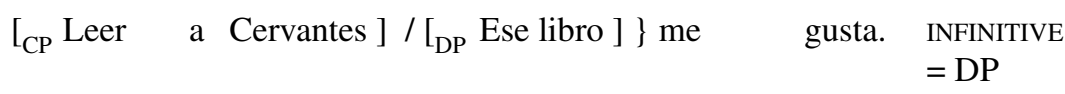
read-INF to Cervantes that book CL-to.me like-3.SG 'I like $\{$ reading Cervantes / this book $\}$ '

(2) Ese es un libro $\left\{\left[_{\mathrm{CP}}\right.\right.$ premiado por la crítica $] /\left[_{\mathrm{AP}}\right.$ interesante $\left.]\right\}$ PARTICIPLE $=$ AP that be-3.SG a book awarded-PPART by the critics interesting 'This is a(n) \{interesting book / book awarded by critics\}'

(3) Luis disfruta $\left\{\left[_{\mathrm{CP}}\right.\right.$ leyendo a Cervantes $] /\left[_{\mathrm{AdvP}}\right.$ así $\left.]\right\}$ GERUND $=$ AdvP Luis enjoy-3.SG read-GER to Cervantes this-way 'Luis enjoys \{reading Cervantes / this way\}'

Different ways to implement this traditional observation come to mind, but all of them must face a question that has become hotly debated in the recent literature: what is the nature of lexical categories? In GB-based accounts, this issue did not arise, quite simply because the categorial status of an LI was lexically encoded. However, within more recent approaches, this question must be reconsidered, as the very notion 'category' is controversial: is it a (combination of) feature(s)? Is it the result of combining a $\sqrt{ }$ RoOT and a functional element? Is it the consequence of a configuration / template? (see Baker 2003, Borer 2005, Chomsky 1970, 1981, Hale \& Keyser 1993, Marantz 1997, 2001, and related literature). 
In the following sections, I present an analysis of the data in (1) through (3), arguing that $\mathrm{C}$ can manifest itself in two guises, as $\mathrm{D}$ (i.e., nominal-like) or $\mathrm{P}$ (i.e., non-nominal-like), depending on the inflectional properties of the verb. In particular, I argue for the analyses in (4), whose (interpretive) consequences will be considered in section 4 .

(4) a. INFINITIVE $=\left[{ }_{\mathrm{CP}} \mathrm{C}\left[{ }_{\mathrm{TP}} \mathrm{T}\left[\left[_{\mathrm{v} * \mathrm{P}} \mathrm{V}^{*} \ldots\right]\right]\right]\right.$

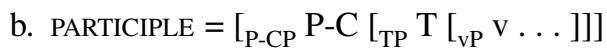

c. GERUND $=\left[{ }_{\mathrm{P}-\mathrm{CP}} \mathrm{P}-\mathrm{C}\left[\left[_{\mathrm{TP}} \mathrm{T}\left[{ }_{\mathrm{v} * \mathrm{P}} \mathrm{V} * \ldots\right]\right]\right]\right]$

As can be seen, the most interesting aspect of the analyses in (4) corresponds to the hybrid nature of the complementizers of both past participles and gerunds, which I treat as a complex P-C element. At first glance, the idea is highly reminiscent of so-called prepositional complementizers (see Kayne 2000 and references therein), but given some facts that I will discuss in section 3, such a comparison will turn out to be not entirely accurate.

I will further extend the proposal in (4) in order to account for the semantic properties of non-finite clauses, which can give rise to different interpretations that I will take to be ultimately rooted in Hale's (1986) central coincidence / non-central coincidence distinction.

\section{The nature of non-finite $C$}

Much literature ever since the late seventies and early eighties (see den Besten 1983, Emonds 1985, and van Riemsdijk 1978; see Pesetsky \& Torrego 2001 for up to date discussion) has underscored the tight connection between the functional categories $\mathrm{T}$ and $\mathrm{C}$, noting, e.g., that the finiteness properties of the former have an effect on the latter, which manifests itself either as a conjunction (e.g., I think that John is happy) or a preposition (e.g., I want for John to be happy). One other wellknown effect of the T-C interaction concerns the type of Case subjects receive: nominative (e.g., John is happy), oblique (I want for John to be happy), or null (I want PRO to be happy).

Quickly enough, these topics were considered in the context of the so-called "DP Hypothesis" (see Abney 1987), arguing for parallelisms like those in (5), where $\mathrm{C}$ and $\mathrm{P}$ were taken as extended (or stretched) projections of verbs and nouns respectively (see Grimshaw 1991, Emonds 1985, and van Riemsdijk 1978; for recent discussion, see Emonds 2009):
a. $\left[_{\mathrm{CP}} \mathrm{C}\left[\left[_{\mathrm{TP}} \mathrm{T}\left[{ }_{\mathrm{VP}} \mathrm{V} \ldots\right]\right]\right]\right.$
b. $\left[{ }_{\mathrm{PP}} \mathrm{P}\left[{ }_{\mathrm{DP}} \mathrm{D}\left[{ }_{\mathrm{NP}} \mathrm{N} \ldots\right]\right]\right]$

In (5), $\mathrm{C}$ and $\mathrm{P}$ could be taken to be contextual versions (i.e., allomorphs) of the same abstract category, a possibility much emphasized in Bittner \& Hale (1996), 
Emonds (1985), Grimshaw (1991), and van Riemsdijk (1978). However, a similar line of inquiry has pursued an alternative in which $\mathrm{C}$ is not akin to $\mathrm{P}$, but to $\mathrm{D}$ (as first argued by Szabolcsi 1992). This hypothesis has been explored in recent work by Pesetsky \& Torrego (2001, 2004):

(6) a. $\left[{ }_{\mathrm{CP}} \mathrm{C}\left[{ }_{\mathrm{TP}} \mathrm{T}\left[\left[_{\mathrm{VP}} \mathrm{V} \ldots\right]\right]\right]\right.$

b. $\left[_{\mathrm{DP}} \mathrm{D}\left[\left[_{\mathrm{PP}}(\mathrm{P})\left[_{\mathrm{NP}} \mathrm{N} \ldots\right]\right]\right]\right.$

One of the insights of Pesetsky \& Torrego's (2004) is that P should be clustered with $\mathrm{T}$, not $\mathrm{C}$, for it is $\mathrm{P}$ and $\mathrm{T}$ that are birrelational predicates (see Demirdache \& Uribe-Etxebarria 2000, Stowell 1993, Zagona 1990). C, in this approach, is more similar to D, as both categories "turn a [predicate/predication] into something that can act as an argument," to quote Szabolcsi (1992). From this perspective, if C looks like a $\mathrm{P}$, it is because of T-to-C movement.

That $\mathrm{C}$ is a species of $\mathrm{D}$ - or has $\mathrm{D}$-like properties - is in fact very plausible on empirical grounds. This would explain why CPs can be antecedents for (null) pronouns, as Picallo (2007) argues (contra Iatridou \& Embick 1997):

$$
\begin{aligned}
& {\left[_{\mathrm{CP}} \begin{array}{l}
\text { Que el } \mathrm{F} 10 \text { sea un poco lento }]_{\mathrm{i}} \text { preocupa a Alonso... } \\
\text { that the } \mathrm{F} 10 \text { be-SUBJ.3.SG a bit slow worry-3.SG to Alonso }
\end{array}\right.} \\
& \text {... pero pro }{ }_{\mathrm{i}} \text { alegra a } \\
& \text { but } \quad \text { make-happy.3.SG to Vettel }
\end{aligned}
$$

'The F10 being a bit slow worries Alonso, but (it) makes Vettel happy'

Picallo (2007: 104 and ff.) restricts this property to C, arguing that TP cannot be an antecedent for a pronoun. (8), however, is at odds with this assumption, for we have a defective - CP-less - clause, which can nonteheless be taken as antecedent by the pronoun eso (Eng. that). ${ }^{2}$

(8) Juan parece $\left[_{\mathrm{TP}} \text { tener demasiado trabajo }\right]_{\mathrm{i}}$ pero eso $_{\mathrm{i}} \ldots$

Juan seem-3.SG have-INF too-much work but that ... no impide que juegue con sus hijas.

(Spanish) not prevent-3.SG that play-SUBJ.3.SG with his daughters

'Juan appears to have too much work, but this does not prevent him from playing with his daughters'

Another piece of evidence in defense of a D layer in the CP domain comes from clauses that are introduced by a definite article in Spanish (see Leonetti 1999). As Uriagereka (1988) noted, this article can only show up in subject, not object

2. As an anonymous reviewer correctly points out, defectiveness is not an agreed upon term (see Gallego 2009, 2010 for discussion). For the most part I will use this label in order to refer to categories that lack some features and therefore cannot assign strutcural Case (roughly, as in Chomsky 2000, 2001). For alternative conceptions of defectiveness, I refer the reader to Pesetsky \& Torrego (2007) and Rizzi (1994, 1995). 
CPs (but see Serrano 2008 for some subjunctive-taking verbs manifesting a different behaviour):
a. $\left[_{\mathrm{CP}} \mathrm{El}\right.$ que vengas ]
les impresiona.
the that come-SUBJ.2.SG CL-to.them impress-3.SG
(Spanish)
'That you come impresses them'
b. *Quieren $\left[{ }_{\mathrm{CP}}\right.$ el que vengas ]
want-3.PL the that come-SUBJ.3.SG
'They want that you come'
(Spanish)

[from Uriagereka 1988: 121-122]

The facts in (9) are not surprising if, much like object DPs, object CPs are not doubled by a clitic in Peninsular Spanish. From this evidence, one could assume that CPs involve an extra D layer, roughly as indicated in (10): ${ }^{34}$

(10) $\left[{ }_{\mathrm{DP}} \mathrm{D}\left[\left[_{\mathrm{CP}} \mathrm{C}\left[_{\mathrm{TP}} \mathrm{T} \ldots\right]\right]\right]\right.$

With this background in mind, let us go back to the nature of non-finite forms. Most current and previous work (see Belletti 1990, Chomsky 2001, López 1994, Hernanz 1994, Pires 2006, and references therein) agrees that these forms are, in one form or another, defective - where 'defective' is usually taken to mean 'lack of some projection(s)' (see fn. 2) - It is important to point out, in this respect, that nonfinite forms are not equally defective: in particular, it has often been noted that participles are more defective than both infinitives and gerunds, as only the former fail to license external arguments, accusative Case, and negation (see Hernanz 1994 and references therein). This is shown in (11) and (12). ${ }^{5}$

3. I assume that the alleged D layer contains only [person], not [number]. That would account for the agreement facts noted by Picallo (2002), which indicate that CPs do not trigger number agreement, even if they are coordinated. I am sweeping under the rug facts of languages like Basque, which show that CPs are introduced by a bona fide D. See Etxepare (2006), San Martin (2004), and San Martin \& Uriagereka (2002) for more discussion.

4. The presence of a D poses the problem of creating a complex-NP barrier, in the sense of Ross' (1967). To get around this, one could assume, following Uriagereka (1988), a process of determiner cliticization whereby D is incorporated into $\mathrm{v}^{*}$, destroying barrier-like effects.

5. I assume that the subject Juan in (11c) is within the infinitival clause — plausibly as a PRO double, perhaps as a proof that control is raising, a possibility I leave open (see Alexiadou et al. 2010, Boeckx et al. 2010, Hornstein 1999, 2001, 2003)—. In general, subjects are allowed when the infinive occupies a 'non-governed' position (see Rigau 1993), but I take (11c) to indicate that subjects can also appear in governed ones. For more recalcitrant data, I refer the reader to Hernanz (1999). 
(11) a. $\left[_{\mathrm{CP}}\right.$ Recogido (*Juan) el dinero], nos iremos. pick-up-PPART Juan the money CL-we go-FUT.1.PL

(Spanish)

'Once the money has been picked up (by Juan), we will leave'

b. $\left[_{\mathrm{CP}}\right.$ Recogiendo Juan el dinero], no habrá

problemas.

(Spanish)

pick-up-GER Juan the money not there-be-FUT.3.SG problems

'If Juan picks up the money, there will be no problem'

c. Quiere $\quad\left[{ }_{\mathrm{CP}}\right.$ recoger Juan el dinero $]$

want-3.SG pick-up-INF Juan the money

(Spanish)

'Juan wants to pick up the money'

(12) a. $\left[_{\mathrm{CP}}(\right.$ ?*No) recogido el dinero], nos iremos.

not pick-up-PPART the money CL-we go-FUT.1.PL

(Spanish)

'The money not being picked up, we will leave'

b. $\left[_{\mathrm{CP}}(\mathrm{No})\right.$ recogiendo Juan el dinero], no habrá

problemas.

(Spanish)

not pick-up-GER Juan the money not there-be-FUT.3.SG problems 'If Juan does not pick up the money, there will be no problems'
c. Juan decidió
${ }_{\mathrm{CP}}$ no venir $]$
Juan decide-PAST.3.SG not come-INF
'Juan decided not to come'

(Spanish)

Put together, these facts suggest that infinitives and gerunds contain a vP structure richer than that of past participles. Building on the fact that accusative Case is assigned by infinitives and gerunds, I assume that these forms project a $\varphi$-complete $\mathrm{V} * \mathrm{P}$, contrary to past participles, which feature a $\varphi$-defective vP, lacking [person]. ${ }^{6}$ The next question is what the CP phase of non-finite clauses looks like: if the possibility for nominative Case to be assigned is all that matters to decide this, then the $\mathrm{C}$ of all these forms is $\varphi$-complete. This is in fact argued by both Rigau (1993) and Torrego (1998), who take infinitivals to have rich (abstract) agreement, but weak

6. Independent evidence for this approach may be gathered from clitic climbing (see Cinque 2006). As (i) and (ii) show, this process is barred in negative contexts.

(i) Lo quiero (*no) ver.

CL-him want-1.SG not see-INF

(Spanish)

'I do not want to see him'

(ii) Le puedo (*no) ayudar.

CL-him can-1.sG not help-INF

'I cannot help him'

(Spanish)

A way of interpreting these facts is to assume that negation can only show up in strong (accusativelicensing) phases (see Solà 2002 for an account compatible with this). If so, then clitics receive Case and freeze, which would explain why further A-movement (i.e., clitic climbing) fails. 
tense. Let us assume, therefore, the structures in (13), where I use the * superscript to indicate $\varphi$-completeness in both $\mathrm{v}$ and $\mathrm{C}$ :
(13) a. $\left[{ }_{\mathrm{C} * \mathrm{P}} \mathrm{C}^{*}\left[{ }_{\mathrm{TP}} \mathrm{T}\left[{ }_{\mathrm{v} * \mathrm{P}} \mathrm{v}^{*} \ldots\right]\right]\right]$
INFINITIVE
b. $\left[_{\mathrm{C} * \mathrm{P}} \mathrm{C}^{*}\left[{ }_{\mathrm{TP}} \mathrm{T}\left[\left[_{\mathrm{v} * \mathrm{P}} \mathrm{v}^{*} \ldots\right]\right]\right]\right.$
GERUND
c. $\left[{ }_{\mathrm{C} * \mathrm{P}} \mathrm{C}^{*}\left[\left[_{\mathrm{TP}} \mathrm{T}\left[{ }_{\mathrm{vP}} \mathrm{V} \ldots\right]\right]\right]\right.$
PARTICIPLE

Under (13), the CP layer of all non-finite forms is identical, for infinitives, past participles, and gerunds license nominative Case. What makes these forms differ concerns the vP structure. Accordingly, the fact that participles cannot license external arguments (pace Collins' 2005 analysis of passives) and negation (see also fn. 6), as the data in (11) and (12) show, is a direct consequence of participial $v$ being $\varphi$-defective.

As just said, the proposal appears to get the right results as long as only Case properties are brought to the fore. The moment additional facts are considered, (13) turns out to be insufficient. Let us see why. To keep discussion to a manageable length, I will focus on two specific facts, which I would like to connect to each other: (i) the possibility for $\mathrm{C}$ to be filled in by a subordinator (a conjunction or preposition), and (ii) the possibility for $\mathrm{C}$ to be in complement (in earlier terminology, 'governed') position. Consider them in turn. As noted by Hernanz (1994), past participles and gerunds cannot have a subordination marker in $\mathrm{C}$ (typically, a preposition, given the non-finite nature of these verbs):

(14) a. (*Por) habiendo demostrado el domador su valentía ... (Spanish) for have-GER show-PPART the tamer his bravery 'The tamer having shown his bravery. ..'

b. (*Sin) leída la sentencia, el juez se retiró. without read-PPART the judgment the judge CL go-PAST.3.SG 'Without the judgment being read, the judge left'

[from Hernanz 1994: 392]

On the other hand, infinitives readily allow for prepositions to introduce them, in both governed and non-governed positions (see Hernanz 1993, Rigau 1993, 1995, and Rizzi 1997):

(15) a. Le amonestaron por mentir.

(Spanish)

CL-him punish-PAST.3.PL for lie-INF

(Spanish)

'He was pubished for lying'

b. Credo di apprezzare molto il tuo libro.

(Italian) believe-1.SG of appreciate-INF much the your book 'I think I like your book a lot'

c. És interessant de fer notar aquest contrast.

(Catalan) be-3.SG interesting of make-INF note-INF this contrast 'It is interesting to point out this contrast' 
Also interesting is the fact, pointed out to me by Juan Romero and M. Lluïsa Hernanz (p.c.), that although verbal periphrases can be formed by combining a functional (be it auxiliary or modal) verb with a $[\mathrm{P}+$ infinitive $]$ cluster, they cannot be formed by combining a functional verb with a $[\mathrm{P}+$ gerund/participle $]$ cluster. Therefore, we can have empezar a gritar (Eng. start to scream), ponerse a cantar (Eng. get to sing), but not empezar a gritando/gritado (Eng. start to screaming/screamed) or ponerse a cantando/cantado (Eng. get to singing/sung). ${ }^{78}$

In Gallego (2010), I took the facts in (14) and (15) at face value, arguing that past participles and gerunds, contrary to infinitives, resist to occupy complement positions. $^{9}$

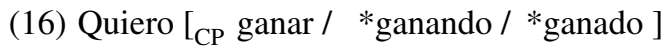

(Spanish)

want-1.SG win-INF GER

PPART

'I want to win/wining/won'

What all these pieces of evidence amount to, in a nutshell, is quite easy to spellout, descriptively at least: both gerunds and past participles are equivalent to an infinitive plus a preposition. Now we have to discuss how strict such an equivalence is.

Let us now go back to the data in (14) and (15). The former are somewhat controversial, as they have been taken to indicate either that there is no CP projection in gerund and past participial clauses (see López 1994, Pires 2006), or else that the verb moves to it, blocking insertion of any other element (see Hernanz 1994); at first glance, either option could account for the fact that the $\mathrm{C}$ head cannot be spelled-out. As for the data in (15), what they show is that infinitivals naturally allow for $\mathrm{C}$ to be spelled-out. Straightforward as these conclusions may

7. See Gallego \& Hernanz (2010) for additional discussion on periphrastic complexes in Spanish.

8. An anonymous reviewer observes that prepositions are not always excluded with gerunds. In order to show this, (s)he provides the example Without looking up, John left. Though interesting, this is not a counterexample to the observation just made, for English gerunds of this sort are not interpreted progressively. Also relevant is that fact that these non-progressive gerunds are impossible in Romance languages, which must resort to an infinitival form instead (see Hernanz 1999, Pesetsky \& Torrego 2004).

9. To be sure, past participles and gerunds can appear in complement positions (in X-bar terms) in periphrastic environments (e.g., passives and progressives). Consider the following examples:

(i) El criminal $_{\mathrm{i}}\left[{ }_{\mathrm{vP}}\right.$ fue $\left[{ }_{\mathrm{vP}}\right.$ arrestado $\left.\left.\mathrm{t}_{\mathrm{i}}\right]\right]$

(Spanish)

the criminal be-3.SG arrested

'The criminal was arrested'

(ii) Los alumnos $\left[_{\mathrm{vP}}\right.$ están $\left[_{\mathrm{v} * \mathrm{P}}\right.$ leyendo el programa $\left.]\right]$

(Spanish)

the students be-3.PL reading the program

'The students are reading the program'

As can be seen, the auxiliaries fue and están can take participles and gerunds as complements. In Gallego \& Hernanz (2010) we attribute this possibility to the fact that these forms are prepositional, which means that they do not have to be Case licensed. If this account is tenable, it explains why participles and gerunds can only be selected by $\varphi$-defective (non-accusative assigning) verbs. 
seem, I want to argue for an alternative view. To be specific, I want to argue that participles and gerunds fail to license a $\mathrm{P}$ because these forms already contain a $\mathrm{P}$, an idea that is present, rather prominently, in Mateu's (2002) analysis of the progressive (and has also been noticed by other scholars; see Bolinger 1971, Masullo 2008, and references therein). According to Mateu (2002), the progressive involves "an unaccusative [read "prepositional'] structure over [the] argument structure lexically associated to the verbal predicate" (Mateu 2002: 77). In fact, as this author points out, gerunds are spelled-out as a preposition plus a nominal-like structure in different languages, like Basque, Dutch, or French. Consider the Basque case.

(17) Jon leihoa apur-tze-n dago.
Jon-ABS window-ABS break-NOM.LOC be-3.SG.ABS
'John is breaking the window'

(Basque)

Roughly, then, breaking in these languages is something like 'in break(ing)'. The following parallelisms, taken from Mateu (2002) and attributed to Bolinger (1971), are relevant in this context too:

(18) a. He is at work - He is working.

b. She is at prayer - She is praying.

c. They went on a hike - They went hiking.

d. They went on a picnic - They went picnicking.

Similar facts have been reported for Spanish by Masullo (2008):

(19) a. de fiesta (lit. of party) - festejando (celebrating)

b. de caza (lit. of hunt) - cazando (hunting)

c. de pesca (lit. of fishing) - pescando (fishing)

d. en movimiento (lit. in motion) - moviéndose (moving)

e. en circulación (lit. in circulation) - circulando (circulating)

f. en crecimiento (lit. in growth) - creciendo (growing)

Consider past participles next. First, as is well-known (see Bosque 1990), these forms have been involved in a diachronic process of grammaticalization that turned some of them into full fledged prepositions. The list in (20), from Masullo (2008), is a sample of this conversion:

(20) salvo (save), excepto (except), incluso (including), dado (given, i.e. in view of), visto (seen, i.e. considering), mediante (by means of), durante (during), etc. 
Second, much like gerunds, past participles allow for a paraphrasis that includes a preposition: ${ }^{10}$

(21) a. arrestado (arrested) - bajo arresto (under arrest)

b. desarmado (unarmed) - sin armas (without weapons)

c. sintonizado (tunned) - en sintonía (in tune)

Technically, what must be asked is how exactly this $\mathrm{P}$ manifests itself in gerunds and past participles. Here I would like to endorse the strongest hypothesis and argue that gerunds and participles are (in their topmost shells) nothing but PPs: this would explain, if I am right, why these forms cannot be Goals of a $\varphi$-complete $\mathrm{v}^{*}$. More precisely, I follow Pesetsky \& Torrego $(2001,2004)$ in that $\mathrm{v}^{*}$ must have an active (i.e., Case-less) Goal. In other words, the reason why $v^{*}$ cannot match a gerund or a past participle is essentially the same reason why $\mathrm{v}^{*}$ cannot match a PP in complement position, as the data in (22) show.

(22) a. Quiero [ ${ }_{\mathrm{CP}}$ ganar / *ganando / *ganado ]

(Spanish) want-1.SG win-INF GER PPART 'I want to win/wining/won'

b. Quiero $\left[_{\mathrm{DP}}\right.$ los libros] / [ $_{\mathrm{PP}}$ de los libros ] want-1.SG the books of the books 'I want the books/of the books'

If this is tenable, then infinitives cannot be PPs, but (something closer to) DPs. ${ }^{11}$ ${ }^{12}$ I assume that this is the correct treatment of governed infinitivals; non-governed ones, though, must be analyzed as PPs too, much like gerunds and past participles. Masullo (2008) provides the data in (23), which I regard as evidence to support this conclusion (see Rigau 1993, 1995 for additional evidence):

10. This analysis could in principle be applied to structures such as (i), which Kayne (2008a) analyzes as involving a covert participle (see (ii)):

(i) You are to return home by midnight.

(ii) You are EXPECTED to return home by midnight.

Under the present account, there is no need to postulate a silent participle: the combination of the preposition to (which can be taken to encode perfective aspect) with the infinitive return counts as a participle.

11. An anonymous reviewer points out a potential contradiction, noting that "if $\mathrm{D}$ is $\mathrm{C}$, and $\mathrm{C}$ is $\mathrm{P}$, then, by transitivity, D is P'. This is inaccurate. In my analysis, $\mathrm{C}$ behaves as a P only after T-to$\mathrm{C}$ movement, and crucially it is only $\mathrm{T}$ that can have a prepositional nature in non-finite contexts. I guess the reviewer is thinking of the correlations between $\mathrm{C}$ and $\mathrm{P}$ that have been noted in the literature (see Emonds 1985, van Riemsdijk 1978, and much related work).

12. The same reviewer asks about the status of the element to in examples like John wants to meet, Mary decided to leave, etc. I assume that this element, despite morphological appearances, is not a preposition, but the spell-out of infinitival morphology (akin to auxiliaries or the $-r(e)$ morpheme in Romance; see Kayne 1997, Solà 1996). 
(23) a. La cabina de teléfono está \{saliendo / al salir $\}$ del the booth of telephone be-3.SG leave-GER to-the leave-INF of-the edificio. building 'The telephone booth is on leaving the building'

b. El edificio está \{pasando/pasado/al pasar\} el puente.

(Spanish) the building be-3.SG pass-GER PPART to-the pass-INF the bridge 'The building is after the bridge'

As can be seen, when the infinitival clause occupies a non-governed position (be it adjunct or predicate like), it requires a preposition.

Before concluding, one last key question is in order: what does it mean for the $\mathrm{C}$ of non-finite verbal forms to be a P or a D. So far, I have not been very explicit about it. Adopting Pesetsky \& Torrego's $(2001,2004)$ system, I assume that there is a syntactic dependency between $\mathrm{C}$ and $\mathrm{T}$, manifested as long-distance Agree in the case of infinitives, but as internal Merge in the case of gerunds and past participles. Crucially, I claim that after T moves to C, it projects (see Donati 2006 for a similar analysis in the case of free relatives): ${ }^{13}$
a. $\left[{ }_{\mathrm{CP}} \mathrm{C}^{*} \ldots\left[{ }_{\mathrm{TP}} \mathrm{T} \ldots\left[\mathrm{V}_{\mathrm{v}} \mathrm{V}^{*} \ldots\right]\right]\right]$
INFINITIVE Agree $(\mathrm{C}, \mathrm{T})$
b. $\left[_{\mathrm{PP}} \mathrm{P}\left[{ }_{\mathrm{CP}} \mathrm{C}^{*} \ldots\left[_{\mathrm{TP}} \mathrm{t}_{\mathrm{T}} \ldots\left[_{\mathrm{v} * \mathrm{P}} \mathrm{v}^{*} \ldots\right]\right]\right]\right]$ GERUND
Internal Merge $(\mathrm{C}, \mathrm{T})$
c. ${ }_{\mathrm{PP}} \mathrm{P}\left[{ }_{\mathrm{CP}} \mathrm{C}^{*} \ldots\left[_{\mathrm{TP}} \mathrm{t}_{\mathrm{T}} \ldots\left[\mathrm{v}_{\mathrm{v} * \mathrm{P}} \mathrm{v} \ldots\right]\right]\right]$
PARTICIPLE Internal Merge (C, T)

The key aspect of $(24 \mathrm{~b}, \mathrm{c})$ is, of course, why T projects as a P. Building on ideas by Demirdache \& Uribe-Etxebarria (2000) and Pesetsky \& Torrego (2004), I assume that $\mathrm{T}$ manifests itself as a $\mathrm{P}$ in non-finite contexts, but as a tense morpheme in finite ones. Importantly, this $\mathrm{T} \rightarrow \mathrm{P}$ conversion only holds for gerunds and past participles. Why? The answer must lie on the morphological properties of these non-finite forms. Tentatively, I propose that $-n d o$ (Eng. ing) and -do/a(s) (Eng.

13. A reviewer raises a couple of technical issues about the analysis. The first one concerns Chomsky's $(2007,2008)$ suggestion that the properties of $\mathrm{T}$ are derivative from $\mathrm{C}:$ as the reviewer notes, it is not clear what T-to-C movement is doing if this is correct. The second issue has to do with the too local nature of T-to-C movement, which would be precluded under anti-locality (see Abels 2003). The first issue is not problematic if one assumes that tense and categorial properties are anchored to T (a possibility that Chomsky 2007 himselfs leaves open, for his system only forces $\varphi$-features to be inherited). As for the anti-locality problem, it can be tackled if there is some projection between C and T, be it Rizzi's (1997) Fin or Uriagereka's (1988) F. 
$-e d)$ are prepositional heads in nature, which would explain why an extra P cannot show up in C, as Hernanz (1994) correctly observed: ${ }^{14}$

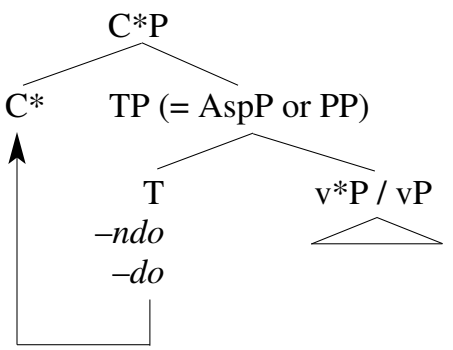

In the next section I would like to elaborate on the analysis in (25) in order to account for some interpretive constraints of non-finite clauses.

\section{Some consequences of the proposal}

In the previous pages I have argued that gerunds and past participles, but crucially not infinitives, are PPs. This does not mean, of course, that they are not verbal too in the relevant sense: what this means is that gerunds and past participles combine a verbal shell with a prepositional one. I assume so, adapting Pesetsky \& Torrego's (2004) analysis of -ing nominalizations (e.g. John's calling the police), in which the upper layer is nominal, and the lower one verbal.

I would like to relate this claim to the observation this paper started with, namely the traditional thesis that non-finite forms are verbal nouns (infinitives), verbal adjectives (past participles), and verbal adverbs (gerunds). The reader may now wonder how come PPs (gerunds and past participles) count as adjectives and adverbs. In this respect, I would like to follow ideas by Mateu (2002), and take it that the lexical categories called "adjective" and "adverb" are derived from the incorporation of a noun-like element into a prepositional-like one. This idea is depicted in (26). ${ }^{15} 16$

$[\mathrm{P}[\sqrt{\mathrm{RoOT}}]]=$ adjective $/$ adverb

14. An anonymous reviewer asks whether the morphological properties of non-finite forms could be seen as reflexes or consequences (instead of causes) of the behavior of non-finite forms. I do not think so, and I do not think the issue is merely technical. The key of my approach is that the (overt) morphology of participles and gerunds be regarded as a preposition of sorts. Consequently, the fact that $-n d o$ and -do prevent the insertion of additional prepositions must be seen as an indication that they have the same nature, and thus compete for the same position.

15. The analysis departs from Marantz's (2001), where adjectives are derived by merging a $\sqrt{ }$ RoOT with a light category dubbed $a$ (djective), being thus more primitive than in Mateu's (2002) system. This analysis also departs from Baker's (2003).

16. One caveat is in order. Mateu (2002) speaks about 'relational' and 'non-relational' elements. The former units are verbs and prepositions (i.e., (bir)relational elements), and the latter are typically nouns. For independent evidence that (relational) adjectives are derived from nouns, I refer the reader to Bosque (2006). 
As Mateu (2002) argues, collapsing PPs, APs, and AdvPs is sound at different levels. To begin with, it is consistent with the fact that adjectives, like nouns and verbs (either denominal or deadjectival), can manifest Case and agreement morphology. This analysis also derives the predicative nature of adjectives and adverbs: since they both encode a preposition, and $\mathrm{P}$ is a (bir)relational element, it follows that they must be related to some element (which will be interpreted as a Figure; see Svenonius 2007, Talmy 2000). Mateu's (2002) proposal also derives the wellknown observation that APs, PPs, and AdvPs can share the same distribution, as the data in (27) show:

\section{(27) a. The cat is $\left[_{\alpha}\right.$ in the room / happy / here ] \\ b. I left John $\left[_{\alpha}\right.$ in the hospital / sick / there ]}

This proposal has independently been pursued by Kayne (2008b), who builds on Amritavalli \& Jayaseelan (2003), and treats adjectives as nouns incorporated into a covert Case morpheme. In the context of the present discussion, one could take $\mathrm{P}$ to be the relevant Case morpheme (a C or K(ase) head, in Bittner \& Hale's 1996 terms). ${ }^{17} 18$ Notice that if this approach is correct, then we have a way to make sense of the traditional observation that we highlighted at the outset of this paper, as well as for the fact that, contrary to infinitives, gerunds and past participles are predicates: this is, quite simply, because of the $\mathrm{P}$ they encode, a relational (= predicative) element.

There are more consequences of this analysis. Consider the fact that past participle and gerund clauses trigger different readings, as discussed by Hernanz (1994). In the examples in (28) and (29), past participle and gerund clauses can yield temporal, causal, and conditional interpretations (the specific reading depending on the morphological properties of the main verb). ${ }^{19}$

17. Importantly, this approach to adjectives does not predict that all PPs must be expressed as adjectives or adverbs in the morphological component. The categorizing effect of prepositions will only work if they are merged with a $\sqrt{ }$ RooT. If it is merged with a noun (an $[n-\sqrt{ }$ RooT $]$ complex, in Marantz 2001) or a DP, we will obtain a PP, not an AP.

18. An obvious question is why, if adjectives and adverbs have the same 1-syntax, only the former can agree with other dependents. Due to space limitations, I leave this issue to the side (see Baker 2008 and references therein).

19. It is worth noting that the appearance of auxiliaries, modals, and negation block some readings (temporal), favouring others (conditional and causal), as Rigau (1995) first noted. Although investigating the interpretive effects of these elements is beyond the scope of this paper, they indicate that auxiliaries behave, at the relevant level of abstraction, like prepositions (see Kayne 1997).

(i) $\mathrm{Al}$ venir María, todos se miraron. to-the come-INF María all CL look-PAST.3.PL

[temporal, causal] 'When/Since María came, all of them looked at each other'

(ii) Al haber venido María, todos se miraron. [*temporal, causal] to-the have-INF come.PPART María all CL look-PAST.3.PL 'Since María had come, all of them looked at each other' 
(28) Leído el libro, lo \{devolví/devolveré\}. read-PPART the book CL-it give-back-PAST/FUT.1.SG 'The book read, I \{gave/will give\} it back'

(29) Leyendo el libro, no \{hice/haré $\}$ ruido. read-GER the book not do-PAST/FUT.1.SG noise 'Reading the book, I will not make noise'

[temporal, causal, conditional]

Interestingly (and rather puzzlingly), other adverbial interpretations, like purpose, can never obtain with past participles or gerunds. Put differently, (30a) cannot mean (30b), but it can (30c) or (30d).

(30) a. Leído el libro, irás a la tienda.

(Spanish)

read-PPART the book go-FUT.2.SG to the shop

'Once the book is read, you will go to the shop'

b. Irás a la tienda para leer el libro. go-FUT.2.SG to the shop to read-INF the book

[temporal, causal, conditional] 'You will go to the shop to read the book'
c. Después de leer el libro, irás
a la tienda.
(Spanish) after of read-INF the book go-FUT.2.SG to the shop 'After reading the book, you will go to the shop'
d. Si lees el libro, irás a la tienda.
if read-2.SG the book go-FUT.2.SG to the shop
'If you read the book, you will go to the shop'

(Spanish)

At this point, the obvious question is why some readings, but not others, are available. Hernanz (1994) argues that the interpretive plasticity of non-finite forms follows from their aspectual properties, which she takes to be encoded through an aspect phrase projected above the relevant past participle, roughly as in (31).

(31)

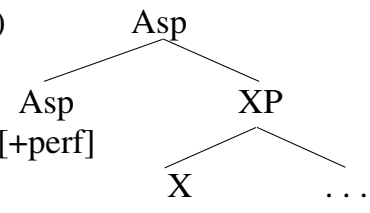
(iii) Al poder venir María, todos se miraron.
to-the be-able-INF come-INF María all CL look-PAST.3.PL
'Since María can come, all of them looked at each other'

[*temporal, causal]

(iv) Al no venir María, todos se miraron.
to-the not come-INF María all CL look-PAST.3.PL

[*temporal, causal] 'Since María did not come, all of them looked at each other' 
In my analysis, Hernanz's (1994) AspP is analogous to the PP that results from T-to-C movement. However, I do not see any obvious way to make the relevant interpretations arise under any of these two accounts. Something else must be added. To solve this, I would like to propose that it is the type of $\mathrm{P}$ that moves to $\mathrm{C}$ (and projects) that is in part responsible for the interpretations non-finite clauses can have. In particular, I will endorse Hale's (1986) seminal distinction between central and non-central (or terminal) coincidence prepositions, which as been exploited to handle different properties of the syntax-semantics interface concerning tense and aspect (see Hale \& Keyser 2002, Demirdache \& Uribe-Etxebarria 2000, 2008, and references therein). As Demirdache \& Uribe-Etxebarria (2000) point out:

Central coincidence indicates that the location of the figure coincides with the ground. In English this relation is expressed by prepositions such as on, in, at, along, over, and through. Conversely, noncentral coincidence (expressed in English by prepositions such as from, out of, (up) to, onto, and into) indicates that the location of the figure either ends or begins at the ground.

[from Demirdache \& Uribe-Etxebarria 2000: 176]

A further cut is that affecting non-central coincidence prepositions. According to Demirdache \& Uribe-Etxebarria (2000), these divide into centripetal and centrifugal, indicating "movement of the figure toward the ground," and "motion of the figure from the ground", respectively. Demirdache \& Uribe-Etxebarria (2000) invoke this finer distinction in order to distinguish tenses (e.g., future tense is an expression of centripetal motion in their account), and I want to extend it to semantic interpretations like cause, purpose, or condition. Specifically, and in order to capture the different readings that non-finite forms can display, I claim that the $\mathrm{P}$ that moves to $\mathrm{C}$ can be different: gerunds are headed by a central coincidence $\mathrm{P}\left(\mathrm{P}_{\mathrm{C}}\right)$, whereas past participles are headed by a non-central coincidence $\mathrm{P}\left(\mathrm{P}_{\mathrm{T}}\right)$.

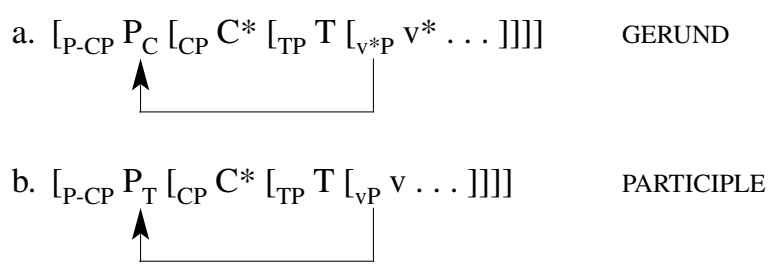

Adopting (32), I propose that notions such as manner, place, purpose, or goal (and many other semantic labels) are conceptual in nature, their grammatical counterpart being a P, either central or non-central (see Roy \& Svenonius 2009 for related ideas). Accordingly, the reason why a purpose interpretation is not available for past participles is that the $\mathrm{P}_{\mathrm{T}}$ these forms contain is centrifugal, so it can only convey meanings that fit with a resultative (therefore, centrifugal) reading. Since, plausibly enough, 'purpose' has a future-oriented (hence, centripetal) nature, past participles cannot be so interpreted. 
To be sure, there are other factors that might conspire to establish the relevant adverbial readings of non-finite clauses. Apart from the tense specification of the matrix clause, elements such as modals, auxiliaries, Aktionsart, and covert quantifiers are good candidates to increase that list. Happily, I think they can all be incorporated to the present account, since all of them can (and have) be(en) analyzed as a species of $\mathrm{P} / \mathrm{T}$ - that is, in fact, the most popular analysis of modals and auxiliaries stemming from Chomsky (1957) -.$^{20} 21$

In this section I have explored some interpretive consequences of the analysis of past participles and gerunds put forward in the previous pages. I have claimed that the relevant interpretation of non-finite clauses (conditional, temporal, causal, etc.) is partially determined by the aspectual properties of the verb at hand (as Hernanz 1994 first argued), which is encoded by means of the $\mathrm{P}$ element (by hypothesis, the morphemes $-n d o$ and $-d o / a(s))$ that moves to $\mathrm{C}$. In the case of gerunds, $\mathrm{P}$ has a central coincidence flavor; in the case of past participles, $\mathrm{P}$ has a non-central (or terminal) flavor. Assuming this much, I have speculated that semantic notions such as purpose, cause, or manner should be seen as conceptual counterparts of $\mathrm{P}_{\mathrm{C}}$ and $\mathrm{P}_{\mathrm{T}}$.

\section{Conclusions}

This paper started by pointing out the observation that non-finite verbs can also behave as if they were nominal, adjectival, and adverbial. I have tried to recast this functional/distributional intuition by capitalizing on the mechanics of Pesetsky \& Torrego's (2001) system. Building on their hypothesis that T-to-C movement is generalized (to satisfy C's demands), I have claimed that the T (slightly more precisely, a 'prepositional $\mathrm{T}$ ') that moves to $\mathrm{C}$ in gerunds and past participles projects. The analysis is appealing at different levels, for it can explain not only selectional facts (assuming $\mathrm{P}$ cannot be a Goal of $\varphi$-Probes), but also the categorial status of these verbs (assuming Mateu's 2002 decomposition of adjectives and adverbs as involving a preposition). In addition, the fact that gerund and past participle clauses cannot be introduced by prepositions (as Hernanz 1994 argued on empirical grounds) follows from these verbs already containing such an element (presumably, encoded in the $-n d o /-d o / a(s)$ morphemes).

I have pushed the analysis in order to account for some interpretive contraints that so-called 'absolute clauses' are subject to. If the account outlined here is on track, and participial $\mathrm{P}$ has a non-central coincidence flavor, then it should come as no surprise that certain interpretations (most pressingly, prospective-like ones) fail to emerge. It is therefore correct that the aspectual properties of participles restrict the relevant readings (see Hernanz 1994).

20. The same holds for quantification, which is the key property of conditional interpretations (see Hernanz 1993), if Fox \& Nissenbaum's (2003) analisys of Ps as QR inducers is on the right track.

21. An anonymous reviewer points out that it is unaccurate to refer to Chomsky's (1957) analysis of modals and auxiliaries, since "Chomsky 1957 doesn't treat modals as Ts (T was not there in the theory)". To be sure, T was not available in Chomsky's (1957) account, but this is how Chomsky himself recast his 1957 analysis (see Chomsky 1981:1410, 1986:160-161). 
These investigations point to different, and more general, conclusions. One of them is that although we take gerunds and past participles to be verbs, they actually have a strongly prepositional nature. ${ }^{22}$ Another conclusion that can be drawn is that what we call T / P can be the locus of different interpretations, depending on where it is merged: if merged below $\mathrm{v}^{*}, \mathrm{~T} / \mathrm{P}$ conveys locative and aspectual interpretations (see Hale \& Keyser 2002, Torrego 1999); if merged above v, T / P conveys grammatical aspect interpretations (see Demirdache \& Uribe-Etxebarria 2000); and if merged in the CP area (either below or above $\mathrm{C}$ ), $\mathrm{T} / \mathrm{P}$ conveys temporal and modal interpretations of different kinds (see Pestetsky \& Torrego 2001, 2004, Demirdache \& Uribe-Etxebarria 2008), these covering what I have called 'adverbial readings' (conditional, purpose, etc.).

Torrego (2006) is one such work providing evidence that prepositions can be used to yield a modal reading: (33a) has the meaning of (33b).

$$
\begin{aligned}
& \text { a. Juan es de comer mucho. } \\
& \text { Juan be-3.SG of eat-INF much } \\
& \text { 'Juan is of to eat a lot' } \\
& \text { b. Juan suele comer mucho. } \\
& \text { Juan use-3.SG eat-INF much } \\
& \text { 'Juan is used to eating a lot' }
\end{aligned}
$$

Similar observations have been reported (but never given a comprehensive account, to my mind) in data like those in (34), where the infinitive has a modal interpretation, sometimes because of an overt $\mathrm{P}$, sometimes because of a covert one (an idea that was suggested by Ian Roberts in 1985 for subjunctives; see also Bhatt 1999 and Hernanz 1999):

22. An anonymous reviewer observes that "verbs also have a strongly prepositional nature, so why can't gerunds be Vs (by transitivity)?'. A couple of comments is in order. Firstly, let me emphasize that in the analysis put forward in this paper, past participles and gerunds are verbs (otherwise, the latter would not assign accusative Case and the former would preclude VP adjuncts, contrary to fact). What I am saying is that, apart from their clearly verbal nature, past participles and gerunds are also prepositional. Secondly, I do not quite understand the observation that "[all?] verbs have a strongly prepositional nature". If I interpret him/her correctly, the reviewer is thinking of the possibility that (some) verbs involve a process of $\mathrm{P}$ incorporation (e.g., location and locatum verbs in Hale \& Keyser 1993 and much related literature). This is correct, and I have no good answer as to why this process does not have an effect analogous to that of T-to-C movement in non-finite verbs. It could be argued that incorporation takes place in the PF branch (as Hale \& Keyser 2002 suggest), and thus lacks syntactic effects. Alternatively, one could argue that $\mathrm{P}$ incorporation in location and locatum verbs targets the head of the VP, which is an inner layer within the vP phase. If the $\mathrm{P}$ is too buried within the $\mathrm{vP}$ structure, then it is expected that the prepositional nature of these classes of verbs is somehow invisible. 
(34) a. Tengo cosas [ ${ }_{\mathrm{PP}}$ por/sin / que hacer]

(Spanish) have-1.SG things for without that do-INF 'I have things to do'

b. No tengo $\quad\left[{ }_{\mathrm{CP}}\right.$ donde dormir $]$ not have-1.SG where sleep-INF 'I don't have where to sleep'

The examples in (34) strongly recall 'parasitic gaps' (see Bosque 1990, 1999, Masullo 1992, Nissenbaum 2000; see 35 below), another topic that, to the best of my knowledge, has been largely (if not entirely) neglected in the recent literature on Spanish.

(35) a. Qué libro devolviste sin leer? what book return-PAST.2.SG without read-INF

(Spanish) 'Which book did you return without reading?'

b. Qué ejercicio te queda por hacer? what exercise CL-to.you remain-3.SG for do-INF

(Spanish) 'Which exercise do you have to do yet?

Whether a unitary analysis for all these phenomena can be provided is an open —and indeed challenging — question that I leave for future research.

\section{References}

Abels, Klaus (2003). Successive cyclicity, anti-locality, and adposition stranding. $\mathrm{PhD}$ dissertation, UConn.

Abney, Steven (1987). The English Noun Phrase in Its Sentential Aspect. PhD dissertation, MIT.

Alexiadou, Artemis; Anagnostopoulou, Elena; Iordachioaia, Gianina; Marchis, Mihaela (2010). "No objection to Backward Control". In: Hornstein, N.; Polinsky, M. (eds.). Movement theory of Control. Amsterdam: John Benjamins, pp. 89-118.

Amritavalli, R.; Jayaseelan, K. A. (2003). "The genesis of syntactic categories and parametric variation”. In: Yoon, H.-J. (ed.). Generative Grammar in a Broader Perspective: Proceedings of the 4th GLOW in Asia 2003. Seoul: Hankook.

Baker, Mark C. (2003). Lexical categories. Verbs, nouns, and adjectives. Cambridge: Cambridge University Press.

Baker, Mark C. (2008). The Syntax of Control and Agreement, Cambridge: Cambridge University Press.

Bhatt, Rajesh (1999). Covert Modality in Non-Finite Contexts. PhD dissertation, University of Pennsylvania.

Belletti, Adriana (1990). Generalized verb movement. Aspects of verb syntax. Torino: Rosenberg \& Sellier.

Bello, Andrés (1847). Gramática de la lengua castellana, destinada al uso de los americanos, edición con notas de Rufino José Cuervo (2 vols.). Ramón Trujillo (ed.). Madrid: Arco/Libros. 
Bittner, Maria; Hale, Kenneth (1996). "The Structural Determination of Case and Agreement". Linguistic Inquiry 27: 1-68.

Boeckx, Cedric; Hornstein, Norbert; Nunes, Jairo (2010). Control as Movement. Cambridge: Cambridge University Press.

Bolinger, Dwight (1971). "The Nominal in the Progressive”. Linguistic Inquiry 2: 246-250.

Borer, Hagit (2005). Structuring Sense (2 vols.). Oxford: Oxford University Press.

Bosque, Ignacio (1989). Las categorías gramaticales. Madrid: Síntesis.

Bosque, Ignacio (1990). "Sobre el aspecto en los adjetivos y los participios". In: Bosque, I. (ed.). Tiempo y aspecto en español. Madrid: Cátedra, pp. 177-214.

Bosque, Ignacio (1999). "El sintagma adjetival. Modificadores y complementos del adjetivo. Adjedtivo y participio". In: Bosque, I.; Demonte, V. (eds.). Gramática descriptiva de la lengua española. Madrid: Espasa, pp. 216-309.

Bosque, Ignacio (2006). "Coordinated adjectives and the interpretation of number features”. In: Brugè, L. (ed.). Studies in Spanish Syntax. Venezia: Libreria Editrice Cafoscarina, pp. 47-60.

Chomsky, Noam (1957). Syntactic Structures. The Hague: Mouton.

Chomsky, Noam (1970). "Remarks on nominalization". In: Jacobs, R.; Rosenbaum, P. (eds.). Readings in English transformational grammar. Waltham, MA: Ginn and Co, pp. 184-221.

Chomsky, Noam (1981). Lectures on Government and Binding. Dordrecht: Foris Publications.

Chomsky, Noam (1986). Knowledge of language. Its nature, origin, and use. New York: Praeger.

Chomsky, Noam (2001). "Derivation by phase". In: Kenstowicz, M. (ed.). Ken Hale: A life in language. Cambridge, MA: MIT Press, pp. 1-52.

Chomsky, Noam (2007). "Approaching UG from below”. In: Sauerland, U.; Gärtner, H-M. (eds.). Interfaces + recursion = language? Chomsky's minimalism and the view from syntax-semantics. Berlin: Mouton de Gruyter, pp. 1-30.

Chomsky, Noam (2008). "On phases". In: Otero, C. et al. (eds.). Foundational issues in linguistic theory. Essays in honor of Jean-Roger Vergnaud. Cambridge, MA: MIT Press, pp. 134-166.

Cinque, Guglielmo (2006). Restructuring and Functional Heads. The Cartography of Syntactic Structures (vol. 4). Oxford, NY: Oxford University Press.

Collins, Collins (2005). "A smuggling approach to the passive in English". Syntax 8: 81-120.

Demirdache, Hamida; Uribe-Etxebarria, Myriam (2000). "The primitives of temporal relations". In: Martin, R. et al. (eds.). Step by step. Essays on minimalist syntax in honor of Howard Lasnik. Cambridge, MA: MIT Press, pp. 157-186.

Demirdache, Hamida; Uribe-Etxebarria, Myriam (2008). "Morfosintaxis e interpretación temporal de los verbos modales". In: Carrasco, A. (ed.). Tiempos compuestos y formas verbales complejas. Madrid-Frankfurt: Iberoamericana-Vervuert, pp. 443-497.

Den Besten, Hans (1983). "On the interaction of root transformations and lexical deletive rules". In: Abraham, W. (ed.). On the formal syntax of westgermania. Amsterdam: John Benjamins, pp. 47-131.

Donati, Caterina (2006). “On wh-head movement”. In: Cheng, L.; Corver, N. (eds.). Wh-movement: moving on. Cambridge, MA: MIT Press, pp. 21-46. 
Emonds, Joseph (1985). A Unified Theory of Syntactic Categories. Dordrecht: Foris.

Emonds, Joseph (2009). "Valuing V features and N features: What adjuncts tell us about case, agreement, and syntax in general". In: Brucart, J. M. et al. (eds.). Merging Features. Oxford, NY: Oxford University Press, pp. 194-234.

Etxepare, Ricardo (2006). "Number long-distance agreement in (substandard) Basque". In: Lakarra, J. A.; Hualde, J. I. (eds.). Studies in Basque and historical linguistics in memory of L. R. Trask. Donostia-San Sebastián: Diputación Foral de Gipuzkoa, pp. 303-350.

Folli, Rafaella; Harley, Heidi (2005). "Consuming Results in Italian and English: Flavors of v". In: Kempchinsky, P.; Slabakova, S. (eds.). Aspectual Inquiries. Springer: Dordrecht, pp. 95-120.

Fox, Danny; Nissenbaum, Jon (2003). "VP ellipsis and the position of adverbs". Snippets 7: 7-8.

Gallego, Ángel J. 2009. "Defective C-T in Romance”. Probus 21: 163-216.

Gallego, Ánge J. 2010. Phase Theory. Amsterdam: John Benjamins.

Gallego, Ángel J.; Hernanz, M. Lluïsa (2010). "Tipos de T(iempo) defectivo". Ms., CLT-UAB.

Grimshaw, Jane (1991). "Extended projections”. Ms., Brandeis University.

Hale, Kenneth (1986). "Notes on world view and semantic categories: some Warlpiri examples". In: Muysken, P.; van Riemsdijk, H. (eds.). Features and Projections, Studies in Generative Grammar. Dordrecht: Foris, pp. 233-254.

Hale, Kenneth; Keyser, Samuel J. (1993). "On the argument structure and the lexical expression of syntactic relations". In: Hale, K.; Keyser, S. (eds.). The view from building 20: Essays in linguistics in honor of sylvain bromberger. Cambridge, MA: MIT Press, pp. 53-109.

Hale, Kenneth; Keyser, Samuel J. (2002). Prolegomenon to a theory of argument structure. Cambridge, MA: MIT Press.

Halle, Morris; Marantz, Alec (1993). "Distributed morphology and the pieces of inflection”. In: Hale, K.; Keyser, S. (eds.). The view from building 20. Essays in honor of Sylvain Bromberger. Cambridge, MA: MIT Press, pp. 111-176.

Harley, Heidi (2005). "How do verbs get their names? Denominal verbs, manner incorporation, and the ontology of verb roots in English". In: Erteschik-Shir, N.; Rapoport, T. (eds.). The syntax of aspect: Deriving thematic and aspectual interpretation. Oxford, NY: Oxford University Press, pp. 42-64.

Hernanz, M. Lluïsa (1993). "A propósito de los adjuntos libres”. In: Viana, A. (ed.). Sintaxi. Teoria i perspectives. Lleida: Pagès, pp. 125-173.

Hernanz, M. Lluïsa (1994). "Concordancia, rección y aspecto: las construcciones absolutas en español”. In: Alonso, A. et al. (eds.). II encuentro de lingüistas y filólogos de España y México. Salamanca: Universidad de Salamanca, pp. 367-402.

Hernanz, M. Lluïsa (1999). "El infinitivo". In: Bosque, I.; Demonte, V. (eds.). Gramática descriptiva de la lengua española. Madrid: Espasa, pp. 2197-2356.

Hornstein, Norbert (1999). "Movement and Control". Linguistic Inquiry 30: 69-96. Hornstein, Norbert (2001). Move! A minimalist theory of construal. Oxford: Blackwell. Hornstein, Norbert (2003). "On control”. In: Hendrick, R. (ed.). Minimalist syntax. Oxford: Blackwell, pp. 6-81.

Iatridou, Sabine; Embick, David (1997). “Apropos pro”. Language 73: 58-78. 
Kayne, Richard S. (1997). "The English complementizer of'. Journal of Comparative Germanic Linguistics 1: 43-54.

Kayne, Richard S. (2000). Parameters and Universals. Oxford: Oxford University Press.

Kayne, Richard S. (2008a). "Comparative syntax and the lexicon". Talk given at the Universitat Autònoma de Barcelona, Bellaterra, October 22-23 2008.

Kayne, Richard S. (2008b). "Antisymmetry and the lexicon". Ms., NYU.

Leonetti, Manuel (1999). "El artículo”. In: Bosque, I.; Demonte, V. (eds.). Gramática descriptiva de la lengua española. Madrid: Espasa, pp. 787-890.

López, Luis (1994). "The Internal Structure of Absolute Small Clauses". Catalan Working Papers in Linguistics, 4: 45-92.

Marantz, Alec (1997). "No escape from syntax: Don't try morphological analysis in the privacy of your own lexicon". In: Dimitridades, A. et al. (eds.). UPenn WPL 4. UPenn Publications, pp. 201-225.

Marantz, Alec (2001). "Words". Ms., MIT.

Masullo, Pascual (1992). Incorporation and Case Theory in Spanish: A Crosslinguistic Perspective. $\mathrm{PhD}$ dissertation, University of Washington

Masullo, Pascual (2008). "The syntax-lexical interface. Prepositionalizing motion verbs in Spanish". Ms., University of Pittsburgh.

Mateu, Jaume (2002). Argument Structure: Relational construal at the Syntax-Semantic Interface. Ph.D. dissertation, UAB.

Nissenbaum, Jonathan (2000). Investigations of covert phrase movement. $\mathrm{PhD}$ dissertation, MIT.

Pesetsky, David (1995). Zero syntax. Experiencers and cascades. Cambridge, MA: MIT Press.

Pesetsky, David; Torrego, Esther (2001). "T-to-C movement: Causes and consequences". In: Kenstowicz, M. (ed.). Ken Hale: A life in language. Cambridge, MA: MIT Press, pp. 355-426.

Pesetsky, David; Torrego, Esther (2004). "Tense, Case, and the nature of syntactic categories”. In: Guéron, J.; Lecarme, J. (eds.). The syntax of time. Cambridge, MA: MIT Press, pp. 495-537.

Pesetsky, David; Torrego, Esther (2007). "The syntax of valuation and the interpretability of features”. In: Karimi, S. et al. (eds.). Phrasal and clausal architecture. Syntactic derivation and interpretation. Amsterdam: John Benjamins, pp. 262-294.

Picallo, M. Carme (2002). "Abstract agreement and clausal arguments". Syntax 5: 116-147.

Picallo, M. Carme (2007). "A propósito de Apropos pro". Cuadernos de Lingüística XIV, IUIOG, 101-107.

Pires, Acrisio (2006). The Minimalist Syntax of Defective Domains. Gerunds and Infinitives. Amsterdam: John Benjamins.

Ramchand, Gillian (2008). Verb Meaning and the Lexicon. A First Phase Syntax. Cambridge: Cambridge University Press.

Real Academia Española (1931). Gramática de la lengua española. Madrid: EspasaCalpe.

Real Academia Española (1973). Esbozo de una nueva gramática de la lengua española. Madrid: Espasa-Calpe. 
Riemsdijk, Henk van (1978). A case study in syntactic markedness: The binding nature of prepositional phrases. Lisse: The Peter de Ridder Press.

Rigau, Gemma (1993). "La legitimació de les construccions temporals d'infinitiu". In: Viana, A. (ed.). Sintaxi. Teoria i perspectives. Lleida: Pagès, pp. 231-252.

Rigau, Gemma (1995). "The properties of the temporal infinitive constructions in Catalan and Spanish". Probus 7: 279-301.

Rizzi, Luigi (1994). "Early null subjects and root null subjects". In: Hoekstra, T.; Schwartz, B. (eds.). Language acquisition studies in generative grammar. Amsterdam: John Benjamins, pp. 151-177.

Rizzi, Luigi (1995). "Some notes on linguistic theory and language development: the case of root infinitives". Language Acquisition 3: 371-393.

Rizzi, Luigi (1997). "The fine structure of the left periphery”. In: Haegeman, L. (ed.). Elements of grammar. Handbook in generative syntax. Dordrecht: Kluwer, pp. 281-337.

Roberts, Ian G. (1985). "Agreement Parameters and the Developement of English Modal Auxiliaries". Natural Language and Linguistic Theory 3: 21-58.

Ross, John R. (1967). Constraints on variables in syntax. PhD dissertation, MIT.

Roy, Isabelle; Svenonius, Peter (2009). “Complex prepositions”. In: François, J. et al. (eds.). Autour de la préposition. Actes du Colloque International de Caen (20-22 septembre 2007). Caen: Presses Universitaires de Caen, pp. 105-116.

San Martin, Itziar (2004). On subordination and the distribution of PRO. PhD dissertation, UMD.

San Martin, Itziar; Uriagereka, Juan (2002). "Infinitival Complementation in Basque". In: Artiagoitia, X. et al. (eds.). Erramu Boneta: Festschrift for Rudolf P.G. de Rijk. Supplements of the International Journal of Basque Linguistics and Philology (ASJU), XLIV, pp. 597-609.

Serrano, Silvia (2008). "Un caso poco estudiado de la subordinación en español: sustantivas en posición de objeto precedidas por el". Ms., IUIOG.

Solà, Jaume (1996). "Morphology and word order in Germanic languages". In: Abraham, W. et al. (eds.). Minimal ideas: Syntactic studies in the minimalist framework. Amsterdam: John Benjamins, pp. 217-251.

Solà, Jaume (2002). "Clitic climbing and null subject languages". Catalan Journal of Linguistics 1: 225-255.

Stowell, Timothy (1993). "The Syntax of Tense". Ms., UCLA

Svenonius, Peter (2003). "Limits on P: Filling in Holes vs. Falling in Holes". Nordlyd 31: 431-445.

Svenonius, Peter (2007). "Adpositions, Particles, and the Arguments they Introduce". In: Reuland, E. et al. (eds.). Argument Structure. Amsterdam: John Benjamins, pp. 63-103.

Svenonius, Peter (2008). "Projections of P". In: Asbury, A. et al. (eds.). Syntax and Semantics of Spatial P. Amsterdam: John Benjamins, pp. 63-84.

Szabolcsi, Anna (1992). "Subordination: Articles and complementizers". In: Kenesei, I.; Pléh, Cs. (eds.). Approaches to Hungarian, Vol.4: The structure of Hungarian. Szeged: JATE, pp. 123-137.

Starke, Michal (2009). "Nanosyntax: A short primer to a new approach to language". Nordlyd 36: 1-6.

Talmy, Leonard (2000). Towards a cognitive semantics. Cambridge, MA: MIT Press. 
Torrego, Esther (1998). "Nominative subjects and PRO-drop INFL”. Syntax 1: 206-219. Torrego, Esther (1999). "Aspect in the prepositional system of Romance". In: Satterfield, T. et al. (eds.). Current Issues in Romance Languages. Amsterdam: John Benjamins, pp. 337-357.

Torrego, Esther (2006). "Predication with Characterizing Sentences in Spanish". In: Fernández, B.; Laka, I. (eds.). Andolin gogoan. Essays in honour of Professor Eguzkitza. Bilbao: Publicaciones de la UPV-EHU, pp. 835-853.

Uriagereka, Juan (1988). On government. PhD dissertation, UConn.

Zagona, Karen (1990). “Time as Temporal Argument Structure”. Ms., University of Washington. 